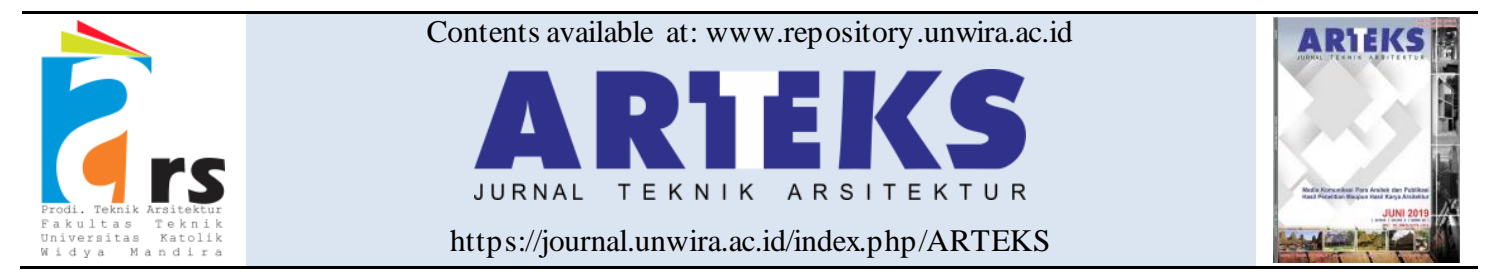

Research paper

doi: 10.30822/arteks.v6i1.595

\title{
Sense of place in Lawas Maspati Village community at Surabaya: Exploration study towards physical, social, and cultural factors
}

\author{
Diyan Lesmana $^{1 *}{ }^{*}$, Antariksa $^{2}\left(\mathbb{D}\right.$, Lisa Dwi Wulandari ${ }^{3}$, Herry Santosa $^{4}$ \\ ${ }^{1}$ Student in the Architecture Doctoral Study Program, Faculty of Engineering, \\ Universitas Brawijaya, Malang, Indonesia \\ 2,3,4 Department of Architecture, Faculty of Engineering, \\ Universitas Brawijaya, Malang, Indonesia
}

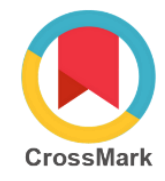

\begin{tabular}{|c|c|}
\hline ARTICLE INFO & ABSTRACT \\
\hline $\begin{array}{l}\text { Article history: } \\
\text { Received June } 28,2020 \\
\text { Received in revised form July } 19,2020 \\
\text { Accepted September } 15,2020 \\
\text { Available online April } 01,2021 \\
\end{array}$ & $\begin{array}{l}\text { The Lawas Maspati Village in the Surabaya urban area has relics } \\
\text { such as historical areas, ancient buildings with colonial } \\
\text { architectural styles, and community cultural traditions such as the } \\
\text { mutual cooperation attribute, cangkrukan (gathering), and local } \\
\text { wisdom (culinary, craft SME). The efforts towards maintaining the }\end{array}$ \\
\hline $\begin{array}{l}\text { *Corresponding author: Diyan Lesmana } \\
\text { Architecture Doctoral Study Program, Faculty } \\
\text { of Engineering, Universitas Brawijaya, } \\
\text { Indonesia } \\
\text { Email: diyan_lesmana75@yahoo.com } \\
\text { ORCID: https://orcid.org/0000-0001-5836- } \\
7997\end{array}$ & $\begin{array}{l}\text { heritage buildings and adapting to cultural dynamics as well as the } \\
\text { local wisdom make Lawas Maspati Village a life diorama which } \\
\text { allows a person to have a sense of place towards the village. This } \\
\text { study was conducted to explore the sense of place in the Lawas } \\
\text { Maspati Village community through physical, social, and cultural } \\
\text { factors through the use of a qualitative descriptive method with a } \\
\text { phenomenological approach. Data were collected through in-depth } \\
\text { interviews and field documentation from respondents selected } \\
\text { through a purposive sampling method using individuals that have } \\
\text { lived for more than } 20 \text { years and aged over } 40 \text { years old. The results } \\
\text { showed the sense of place in Lawas Maspati Village community was } \\
\text { formed by physical, social, and cultural factors including the ancient } \\
\text { colonial-style buildings, historical areas, historical memories in the } \\
\text { struggle period through cultural heritage areas, mutual } \\
\text { cooperation, mutual respect, cangkrukan tradition, friendly } \\
\text { characteristics of Arek Suroboyo such as tolerance, openness, } \\
\text { busyness but friendliness without hurt feelings, traditional culinary, } \\
\text { and religious traditions. }\end{array}$ \\
\hline
\end{tabular}

\section{Introduction}

The development of Surabaya city is inspired by the increasingly diverse demands and needs of the community, especially in terms of facilities, city infrastructure, comfort, and modern urban lifestyle (Patriajaya and Kusliansjah 2019). This further affects all the components of the urban structure, including the urban villages which are known to be unique due to the historical, traditional, social, cultural, and physical characteristics of their buildings and the whole area (Purbadi and Lake 2019). The individuals residing in these villages are important to the process of adapting to the urban development conditions (Bawole 2020).

Every city basically has its unique and distinctive character which is used to form a special identity and spirit differentiating it from other cities (Garnham 1985). Moreover, the spirit of value and meaning provided by inhabitants sustain the quality of city life while the emotional bond or sense of place usually observed between humans and their community is associated with certain special local attributes. Furthermore, the 
sense of belonging encourages humans to protect their living place due to attachment or bonding.

Several studies have been conducted in different fields on the sense of place theme through various points of view and understanding. For example, Kusumowidagdo et al. (2012-2018) examined this concept in commercial areas such as shops and malls as well as religious tourism, and unique road corridors (Kusumowidagdo and Wardhani 2018). Meanwhile, the research on the sense of place in rural communities of urban areas is rare. This study was, therefore, conducted to analyze the physical architectural factors or houses in the Lawas village in relation to social and cultural factors used in forming the community sense of place as the basis to preserve and improve the environmental quality of urban villages in the future.

Phenomenological understanding has shown the concept of place to be a concrete term for the environment (Norberg-Schulz 1991; Van Gerrewey 2012) which has more value than ordinary location. Moreover, phenomenology also observes architecture, as a whole, to be consisting of concrete objects with material substance, shape, texture, and color with properties that cannot be reduced. The environment is also believed to be important to the place's character and quality.

Lawas Maspati is one of the old villages in Surabaya with a distinctive character related to historical events. Old villages are the evidence of the socio-cultural journey of communities as observed in Arek Suroboyo which serves as the bearer of the arek culture with the influence continuously being felt up to the present time (Funo, Yamamoto, and Silas 2002; Silas 1992). The character of Lawas Maspati Village has not faded even though modernity has influenced the economic, social, and cultural aspects of the city. This is observed in the development of the character from the cultural tradition, local wisdom, social cooperation, cangkrukan, crafts, arts, traditional culinary, and historical buildings from the colonial era. This study aimed to identify the sense of place in the old urban village community by describing the physical, social, and cultural factors at the locus in Lawas Maspati Village, Surabaya.

The sense of place involves examining the relationship between humans and their place of residence (Roberson and Wilkie 2010). It describes a holistic concept which focuses on subjectivity and sometimes relates to one's experiences or bonds towards the landscape, emotions, and symbols and also serves as a link between social experiences and geographic areas (Ardoin 2014). The concept changes the meaning of a space into a place and this further indicates the existence of a growing attachment between humans and space. These changes are reflected through the special behavior and emotional characteristics of an individual. Meanwhile, place was defined as a space with a certain meaning and which presents a value to a pers on or community (Ellisa 2016; Letfiani and Widyasari 2015; Ernawati, Santosa, and Setijanti 2013). Humans are, therefore, in a space and live/inhabit a place. This shows space has a broader scope compared to a place.

The place on earth where humans, animals, plants, natural objects, and several other creatures live is called a space (Prijotomo and Pangarsa 2010). The analogy is like primitive humans living in the open but they need protection from nature, animal attacks, weather, and natural disasters and this led them to seekrefuge in caves. The open nature is known as space but also serves as a place when it is used, inhabited, and lived. Moreover, the core meaning of a place is attached to the experiences and other emotional relationships humans have with it (Creswell 2015).

A sense of place has both physical and social characters (Najafi and Shariff 2011). The physical character does not only involve the formation of a physical setting or layout for a space but also contributes to the provision of meaning for a place. Moreover, an easily recognized condition for a particular place with special characteristics influences the relationship between visitors and satisfaction (Najafi and Shariff 2011; Hashemnezhad, Heidari, and Hoseini 2013).

The change of a particular area from space to place is due to the growth and formation of social and emotional bonds. This makes it possible to define place as a space providing a cultural and social experience for an individual. The sense of place, however, becomes quite complex when humans are aware of a place. It is also a multidimensional concept which connects a place where emotional bonds and related physicalsymbolic elements grow. The concept is also a collection of feelings and perceptions both in the conscious and subconscious realms. It subsequently involves an individual's realization, experience, and expression of meaning in a place based on the level of feelings, perceptions, 
attitudes, and behaviors (Axford and Hockings 2005).

Environmental characteristics also play a significant role in shaping meaning and perception apart from being a place marker (Hashemnezhad, Heidari, and Hoseini 2013). Some of the variables observed to be affecting sense of place include dimensions, elements, diversity, tactile value, ornamentation, color, audio disturbances, smells, temperature, entertainment, historical aspects, identity, fun things, aesthetics, vitality, and memories.

Kusumowidagdo and Wardhani (2017) used the landscape and interior to form the physical setting (Kusumowidagdo and Wardhani 2018). The landscape elements include parking, materials, signs, shapes, and scales while the interior elements include shape and finishing, thematic areas, tenant areas, lighting, zoning, air conditioning, rest/sitting areas, and scale of public areas (Kusumowidagdo and Wardhani 2018). Moreover, the physical attributes of a place such as the existence of heritage buildings and the completeness of physical facilities also affect the sense of place (Smith 2011).

The uniqueness of a place as well as visual diversity has the ability to shape the perceptions in an environment and this further affects the sense of place. The use of space in an urban area such as spatial location, attractiveness, and completeness also influence the physical factors of a sense of place (Mirsa 2012).

The increase in the concept based on social factors is, however, characterized by the individual's involvement in society or community through socialization and formation of a sustainable bond (Smith 2011). Individuals that understand society as a social environment strengthen their sense of place by being involved in social activities and those that have lived in a place for a long time tend to have a high sense of place. Moreover, a more intense social involvement of individuals in their environment leads to social satisfaction and comfort and this further increases their sense of place.

The uniqueness of a place including its interesting programs and events attracts visitors with the number of people gathering, both in shopping centers and cafes, has positive influence due to its ability to attract others to join (Herliana, Hanan, and Kusuma 2017; Kusumandayu 2017). This shows the possibility of defining a sense of place in relation to the intentionality towards a place. This relationship is further driven by demographic, social, and environmental experiences.

It is also impossible to separate people's cultural principles from the character of the place they live. Several cultures, traditions, activities, and values adopted by a community are factors influencing the sense of place (Garnham 1985). This is further supported by Najafi and Shariff's (2011) findings that the factors influencing an individuals' relationship with a place include the cultural and activities factors which serve as the key to understanding the characteristics of their interaction with the environment (Najafi and Shariff 2011). Culture was, however, defined as the basis of how people perceive and view life (Herliana, Hanan, and Kusuma 2017). Meanwhile, topophilia is a term used to describe the affective bond between humans and places and has been later developed into terraphilia which emphasizes the territorial aspects of the place (Blake 2018; Oliveira, Roca, and Leitão 2010). Human feelings towards a place become strong due to the occurrence of significant cultural or personalevents (Herliana, Hanan, and Kusuma 2017; Jive'n and Larkham 2003). Moreover, places represent more abstract ideas while culture is seen as part of the activities contributing to human's relation towards their place (Prijotomo and Pangarsa 2010).

\section{Method}

A qualitative-descriptive method with a phenomenological approach was used in this study while the research object is Lawas Maspati Village. The physical, social, and cultural factors of the studied area were examined to determine the sense of place while some individuals or groups were also evaluated to understand the social or humanitarian problems (Creswell 2015). An overview was also provided towards understanding the phenomena related to the experiences such as perceptions, behaviors, actions, and motivations research subjects (Moleong 2017).

Data were collected through observation, interviews, and visually through field documentation. Individuals or groups were observed based on length of stay, respondents age, gender, occupation, and education after which they were also interviewed. 
The sense of place concept was analyzed for physical, social, and cultural factors. The physical factors analysis was conducted on selected heritage buildings which were selected using a purposive sampling method to obtain data which were processed based on predetermined parameters. The primary data were obtained from observations, interviews, and building participatory mapping while secondary data were from literature studies. Moreover, the social factors analysis involving activities and community involvement was conducted in the environment while the cultural factors analysis focused on living equipment, economy, social systems, language, arts, science, and religion.

The sense of place concept used in this study was based on physical fabrics, activities, and generated images (Montgomery 2010) as shown in figure 1 and table 1.

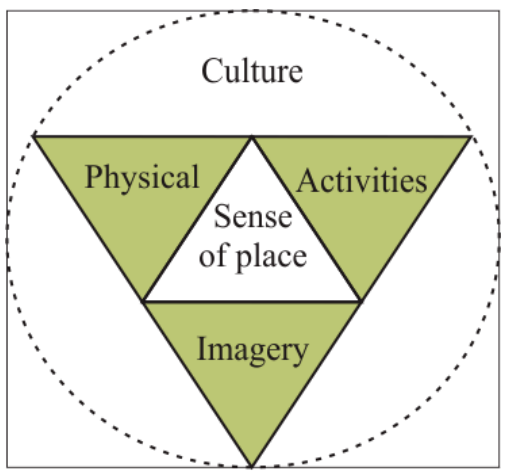

Figure 1. A sense of place diagram by Montgomery (2013)

Table 1. Criteria/parameters from the Sense of Place

\begin{tabular}{ll}
\hline Physical (form) & Criteria/parameters \\
\hline Public realm & $\begin{array}{l}\text { Gaya arsitektur sebagai } \\
\text { gambar (architectural } \\
\text { style as an image) }\end{array}$ \\
\hline Activities & $\begin{array}{l}\text { Extent and variety of } \\
\text { cultural venues }\end{array}$ \\
\hline Street life & $\begin{array}{l}\text { Access to education } \\
\text { providers }\end{array}$ \\
\hline $\begin{array}{l}\text { Small economy (fine grain } \\
\text { economy) }\end{array}$ & Psychological Access \\
\hline Image & \\
\hline Readability (legibility) & \\
\hline Knowledge Ability & \\
\hline Source: (Montgomery 2010)
\end{tabular}

\section{Result and discussion}

Maspati Village has a wide coverage area consisting of alleys I, II, III, IV, V, and VI but this research is limited V and VI due to the existence of several heritage buildings in these alleys which were predicated by the Surabaya City Government in 2016 as "Kampung Lawas Maspati". The location and position of the alleys $\mathrm{V}$ and VI are, therefore, simulated in the following figure 2 .

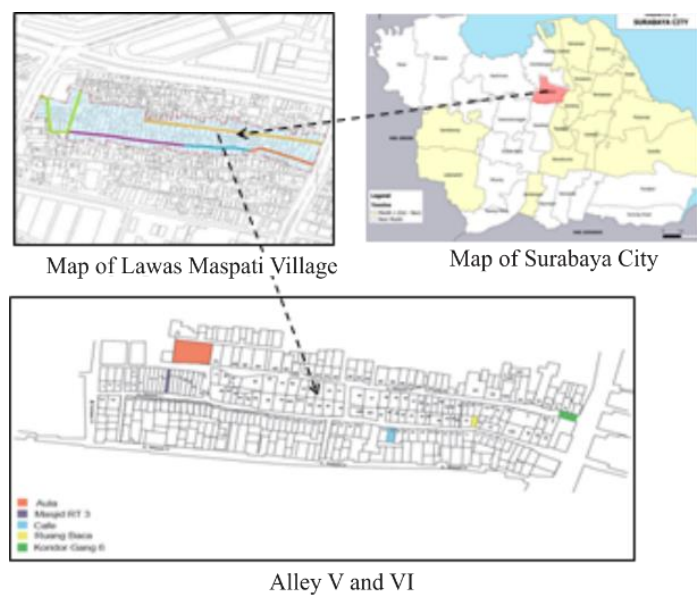

Figure 2. The position, location, and map of Lawas Maspati Village

The houses used as sample were selected based on their strong potential sense of place as indicated by having being in existence for more than 50 years, located in an alley, on the edge of a village $\mathrm{road} /$ facing an alley, and relatively unchanged physically as well as the willingness of the owner to participate. The location and position of some of the selected houses are presented in figure 3 .

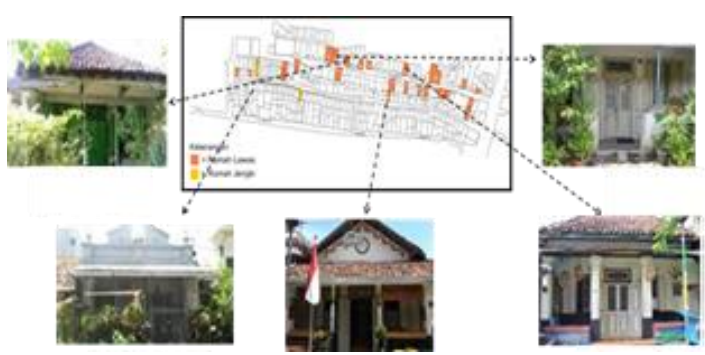

Figure 3. The map of the houses existing for more than 50 years old and with relatively unchanged appearance (Colonial architecture style)

The daily social and cultural activities of the community presented in Figure 4 were assessed to show the efforts made to preserve the local wisdom as a potential factor of the residents' sense of place. 

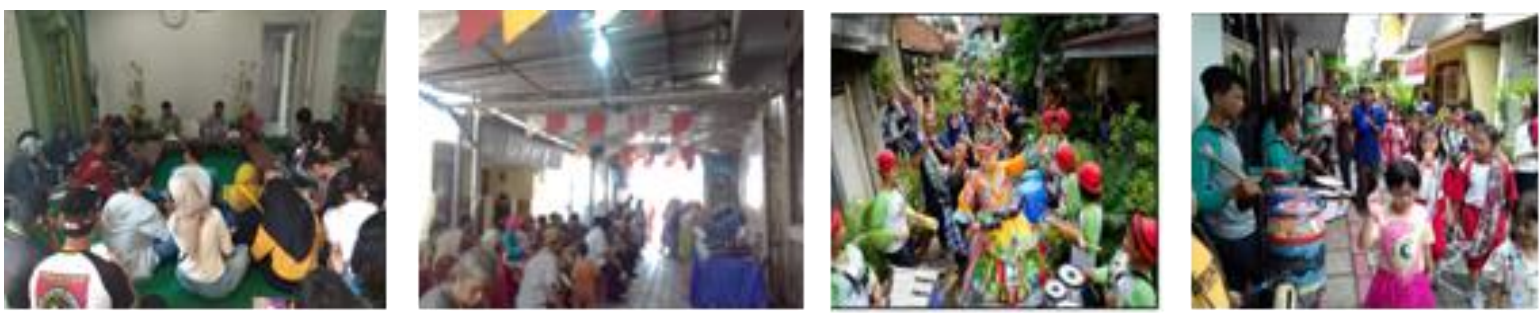

Figure 4. Social and cultural activities (conferences, village festifals and patrolmusic)

The following table shows the results of the questionnaires distributed to 175 respondents in Lawas Maspati Village based on the criteria that they have lived for more than 20 years and are over 40 years old.

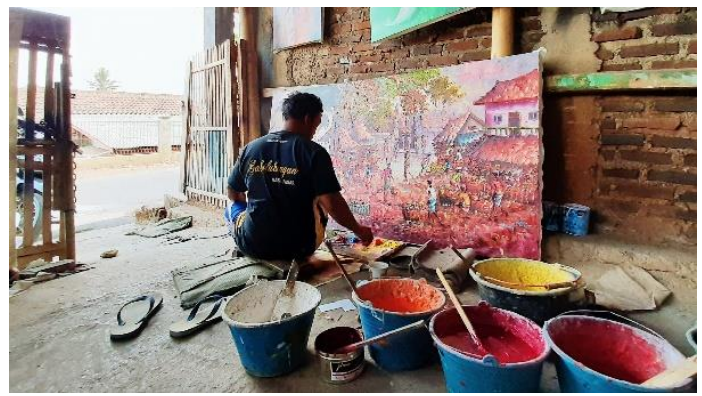

Figure 3. Art activities

The following table 2 shows the results of the questionnaires distributed to 175 respondents in Lawas Maspati Village based on the criteria that they have lived for more than 20 years and are over 40 years old.

Table 2. Results of the questionnaires distributed

\begin{tabular}{llll}
\hline $\begin{array}{l}\text { N } \\
\text { o }\end{array}$ & Aspects/Factors & $\begin{array}{l}\text { Questionnaire } \\
\text { results } \\
\text { (Percentage) }\end{array}$ & Conclusion \\
\hline $\mathbf{1}$ & Physical Factors & & \\
\hline a & $\begin{array}{l}\text { Building } \\
\text { ownership: An } \\
\text { inherited house }\end{array}$ & $40 \%$ & $\begin{array}{l}\text { As an inherited } \\
\text { house, the } \\
\text { family is }\end{array}$ \\
\hline
\end{tabular}

making efforts to maintain its existence and authenticity without changing its appearance

b Trying to maintain There are other the authenticity of $\quad 25 \%$ the building's

Colonial Architecture style and appearance

c Have historical memories

\begin{tabular}{lll}
\hline N & Aspects/Factors & $\begin{array}{l}\text { Questionnaire } \\
\text { results } \\
\text { (Percentage) }\end{array}$ \\
\hline
\end{tabular}

Conclusion

laces/witnesse

s to the

struggle, therefore, the buildings' shape and appearance are maintained.

\begin{tabular}{lll}
\hline $\mathrm{d}$ Have a uniqueness & The \\
& maintenance of
\end{tabular}

facade/appearance $22 \%$ the appearance and this makes it of the old different from building serves others (typical) as evidence of historical travel

e Provide its own characteristics and $14 \%$ identity

The use of the nickname

"Kampung Lawas Maspat" for the village shows it is a historic area

f Located in a $\quad$ Lawas Maspati
historical area and $\quad$ Village is this preserves its $\quad 33 \% \quad$ included in a value cultural heritage

\begin{tabular}{|c|c|c|c|}
\hline $\mathrm{g}$ & $\begin{array}{l}\text { The location of } \\
\text { Lawas Maspati } \\
\text { Village is } \\
\text { strategic }\end{array}$ & $28 \%$ & $\begin{array}{l}\text { Located } \\
\text { between a fairly } \\
\text { dense trade and } \\
\text { service area }\end{array}$ \\
\hline $\bar{h}$ & Closeness to work & $24 \%$ & $\begin{array}{l}\text { Have a very } \\
\text { strategic } \\
\text { location by } \\
\text { being close to } \\
\text { trade and } \\
\text { service areas }\end{array}$ \\
\hline 2 & Social Factors & & \\
\hline $\bar{a}$ & $\begin{array}{l}\text { Societal } \\
\text { characteristics: } \\
\text { community, } \\
\text { mutual } \\
\text { cooperation }\end{array}$ & $67 \%$ & $\begin{array}{l}\text { It increases the } \\
\text { close } \\
\text { relationship } \\
\text { between the } \\
\text { residents of } \\
\text { Lawas Maspati } \\
\text { Village } \\
\end{array}$ \\
\hline $\mathrm{b}$ & $\begin{array}{l}\text { There is a sense of } \\
\text { togetherness, } \\
\text { mutual respect, } \\
\text { and } \\
\text { pleasure/comfort }\end{array}$ & $51 \%$ & $\begin{array}{l}\text { Residents feel } \\
\text { comfortable in } \\
\text { the village due } \\
\text { to the provision }\end{array}$ \\
\hline
\end{tabular}




\begin{tabular}{|c|c|c|c|c|c|c|c|}
\hline $\begin{array}{l}\mathbf{N} \\
\mathbf{0}\end{array}$ & Aspects/Factors & $\begin{array}{l}\text { Questionnaire } \\
\text { results } \\
\text { (Percentage) }\end{array}$ & Conclusion & $\begin{array}{l}\mathbf{N} \\
\mathbf{0}\end{array}$ & Aspects/Factors & $\begin{array}{l}\text { Questionnaire } \\
\text { results } \\
\text { (Percentage) }\end{array}$ & Conclusion \\
\hline & $\begin{array}{l}\text { in the village } \\
\text { atmosphere. }\end{array}$ & & $\begin{array}{l}\text { of comfort and } \\
\text { security. }\end{array}$ & & $\begin{array}{l}\text { traditions } \\
\text { (yasinan/praying }\end{array}$ & & $\begin{array}{l}\text { moment to } \\
\text { maintain }\end{array}$ \\
\hline \multirow[t]{2}{*}{$\mathrm{c}$} & $\begin{array}{l}\text { The existence of a } \\
\text { place for social } \\
\text { activities such as } \\
\text { meeting hall, } \\
\text { public open space, }\end{array}$ & \multirow[t]{2}{*}{$53 \%$} & \multirow[t]{2}{*}{$\begin{array}{l}\text { Community } \\
\text { social activities } \\
\text { are more } \\
\text { focused and } \\
\text { orderly }\end{array}$} & & $\begin{array}{l}\text { with reading } \\
\text { Yasin Surah, } \\
\text { sinoman/youth } \\
\text { voluntary servants } \\
\text { and recitation) }\end{array}$ & & $\begin{array}{l}\text { harmony } \\
\text { between the } \\
\text { people. }\end{array}$ \\
\hline & $\begin{array}{l}\text { and residents' } \\
\text { houses }\end{array}$ & & & \multirow[t]{2}{*}{$\mathrm{e}$} & \multirow{2}{*}{$\begin{array}{l}\text { The development } \\
\text { of local wisdom } \\
\text { activities: } \\
\text { Surabaya's } \\
\text { traditional } \\
\text { culinary business } \\
\text { and craft SME. }\end{array}$} & \multirow[b]{2}{*}{$55 \%$} & $\begin{array}{l}\text { It promotes the } \\
\text { existence and }\end{array}$ \\
\hline $\mathrm{d}$ & $\begin{array}{l}\text { There are routine } \\
\text { activities of the } \\
\text { PKK } \\
\text { (Empowerment of } \\
\text { Family Welfare) } \\
\text { and Youth } \\
\text { organization to } \\
\text { support the }\end{array}$ & $65 \%$ & $\begin{array}{l}\text { It is an } \\
\text { adjustment to } \\
\text { current } \\
\text { communal } \\
\text { activities and } \\
\text { makes the } \\
\text { community } \\
\text { healthier and }\end{array}$ & & & & $\begin{array}{l}\text { survival of } \\
\text { residents by } \\
\text { developing } \\
\text { local specialties } \\
\text { in Suroboyo } \\
\text { such as } \\
\text { craftsmanship } \\
\text { SME. }\end{array}$ \\
\hline
\end{tabular}

on protecting

their

environment

\begin{tabular}{llll}
\hline 3 & Cultural Factors & & \\
\hline a & $\begin{array}{l}\text { Arek Suroboyo } \\
\text { culture }\end{array}$ & $63 \%$ & $\begin{array}{l}\text { The Arek } \\
\text { Suroboyo } \\
\text { traditions and }\end{array}$
\end{tabular}

culture are

maintained by

using a

distinctive

nickname (Cak

- Ning), and

using a typical

Arek Suroboyo

costume when

welcoming

guests. It is a

typical village

culture

currently being promoted.

b Tolerance, friendliness, and $\quad 70 \%$ openness
These are the reflection of people's daily behavior which create a more comfortable, safe, orderly, advanced, and sustainable

village atmosphere

$\begin{array}{lll}\text { c } \begin{array}{l}\text { Performed } \\ \text { cangkrukan }\end{array} 59 \% & \text { The cangknkan } \\ \text { tradition, }\end{array}$
tradition gathering and chat ting as well as intimacy and harmony is created

\begin{tabular}{lll}
\hline $\mathrm{d} \quad \begin{array}{l}\text { Continuous } \\
\text { performance of }\end{array}$ & $\begin{array}{l}\text { It is an activity } \\
\text { continuously } \\
\text { the tradition to } \\
\text { commemorate }\end{array}$ \\
$\begin{array}{l}\text { Independence Day } \\
\text { and religious }\end{array}$ & $61 \%$ & $\begin{array}{l}\text { practiced from } \\
\text { one generation } \\
\text { to another up to } \\
\text { the present }\end{array}$ \\
\hline
\end{tabular}

\section{Conclusion}

The results showed the physical factor used in forming the sense of place in the Lawas Maspati community is the presence of heritage buildings. The village is a unique historical area with several efforts being made to maintain the existence and appearance of old buildings based on their historical memories. The area is located 500 meters from the Tugu Pahlawan Monument and designated as a cultural heritage which also strengthens the sense of place.

Social factors, in the form of community character and behavior with mutual cooperation as well as the implementation of PKK (Empowerment of Family Welfare) activities, Youth Organization, and mutual respect add to the strong sense of place in the area due to their ability to ensure uniqueness. Moreover, the cultural factors manifested in their daily behavior such as a reflection of Arek Suroboyo Culture through tolerance, openness, busyness but friendliness without hurt feelings, developing the cangkrukan tradition, and performing religious traditions, and celebrating Independence Day create a friendly atmosphere and provide a sense of comfort for the community. Furthermore, the local wisdom developed by the community to support the existence of residents by creating traditional Surabaya culinary/snack businesses and craft SME also strengthens the sense of place in the Lawas Maspativillage community. 


\section{References}

Ardoin, Nicole M. 2014. 'Exploring Sense of Place and Environmental Behavior at an Ecoregional Scale in Three Sites'. Human Ecology $42 \quad$ (3): $425-41$. https://doi.org/10.1007/s 10745-014-9652-x.

Axford, Jo, and Marc Hockings. 2005. 'Sense of Place: A Tool to Assist the Meaningful Engagement of Communities in Protected Area Management'. In International Conference on Engaging Communities, edited by Dave Gardiner and Katie Scott. Brisbane, QLD, Australia: Queensland Department of Main Roads. https://www.researchgate.net/publication/434 59675_Sense_of_place_A_tool_to_assist_the _meaningful_engagement_of_communities_i n_protected_area_management.

Bawole, Paulus. 2020. 'The Development of Urban Kampong as One the Alternatives Special Interest Tourism'. ARTEKS : Jurnal Teknik Arsitektur 5 (1): 115-26. https://doi.org/10.30822/arteks.v5i1.362.

Blake, Brian F. 2018. 'Topophilia: A Study of Environmental Perception, Attitudes and Values. By Yi-Fu Tuan'. Journal of Leisure Research 6 (4): 323-25. https://doi.org/10.1080/00222216.1974.1197 0208.

Creswell, John W. 2015. Penelitian Kualitatif \& Desain Riset: Memilih Di Antara Lima Pendekatan. 3rd ed. Yogyakarta: Pustaka Pelajar.

Ellisa, Evawani. 2016. 'Coping with Crowding in High-Density Kampung Housing of Jakarta'. International Journal of Architectural Research: ArchNet-IJAR 10 (1): 195. https://doi.org/10.26687/archnetijar.v10i1.790.

Ernawati, Rita, Happy Ratna Santosa, and Purwanita Setijanti. 2013. 'Facing Urban Vulnerability through Kampung Development, Case Study of Kampungs in Surabaya'. Humanities and Social Sciences 1 (1): https://doi.org/10.11648/j.hss.20130101.11.

Funo, Shuji, Naohiko Yamamoto, and Johan Silas. 2002. 'Typology of Kampung Houses and Their Transformation Process-- A Study on Urban Tissues of an Indonesian City'. Journal of Asian Architecture and Building
Engineering $1 \quad$ (2): 193-200. https://doi.org/10.3130/jaabe.1.2_193.

Garnham, Henry Launce. 1985. Maintaining the Spirit of Place: A Process for the Preservation of Town Character. PDA Publishers Corporation.

Gerrewey, Christophe Van. 2012. 'Christian Norberg-Schulz (1926-2000)'. Environment, Space, Place 4 (1): 29-47. https://doi.org/10.7761/ESP.4.1.29.

Hashemnezhad, Hashem, Ali Akbar Heidari, and Parisa Mohammad Hoseini. 2013. "'Sense of Place" and "Place Attachment". International Journal of Architecture and Urban Development 3 (1): 5-12. https://ijaud.srbiau.ac.ir/article_581_a90b5ac 919ddc57e6743d 8ce32d19741.pdf.

Herliana, Emmelia Tricia, Himasari Hanan, and Hanson Endra Kusuma. 2017. 'Cultural Attachment Sebagai Pembentuk Sense of Place Kampung Bugisan, Yogyakarta'. In Seminar Ikatan Peneliti Lingkungan Binaan Indonesia, C001-8. Jakarta: Ikatan Peneliti Lingkungan Binaan Indonesia. https://doi.org/10.32315/sem.1.c001.

Jive'n, Gunila, and Peter J. Larkham. 2003. 'Sense of Place, Authenticity and Character: A Commentary'. Journal of Urban Design 8 (1): 67-81. https://doi.org/10.1080/13574800320000647 73.

Kusumandayu, Ruly. 2017. 'Analis is Strategi Pengembangan Potensi Kampung Wisata Kreatif Candirejo Di Surabaya'. Tourism, Hospitality and Culinary Journal 2 (2): 1017.

Kusumowidagdo, Astrid, and Dyah Kusuma Wardhani. 2018. 'Investigating a Sense of Place at a Historic Commercial Street Corridor: Visitor Perception of Social Aspects'. In Cities' Identity through Architecture and Arts, edited by Catalani, 1st ed. London, United Kingdom: Taylor \& Francis Group.

Letfiani, Emiria, and Arlita Widyasari. 2015. 'Kampung Maspatias a Sustainable Kampung in Surabaya City'. Journal of Architecture \& ENVIRONMENT 14 (2): 163. 
https://doi.org/10.12962/j2355262x.v14i2.a2 937.

Mirsa, Rinaldi. 2012. Elemen Tata Ruang Kota. Yogyakarta: Graha Ilmu.

Moleong, Lexy J. 2017. 'Metodologi Penelitian Kualitatif (Edisi Revisi)'. In PT. Remaja Rosda Karya.

Montgomery, John. 2010. 'Cultural Quarters as Mechanisms for Urban Regeneration. Part 1: Conceptualising Cultural Quarters'. Planning Practice and Research 18 (4): 293-306. https://doi.org/10.1080/15614260420002156 14.

Najafi, Mina, and Mustafa Kamal Bin Mohd Shariff. 2011. 'The Concept of Place and Sense of Place In Architectural Studies'. World Academy of Science, Engineering and Technology International Journal of Humanities and Social Sciences 5 (8): 105460.

https://doi.org/doi.org/10.5281/zenodo.10822 23.

Norberg-Schulz, Christian. 1991. Genius Loci: Toward a Phenomenology of Architecture. New York: Rizzoli International Publication Inc.

Oliveira, José, Zoran Roca, and Nuno Leitão. 2010. 'Territorial Identity and Development: From Topophilia to Terraphilia'. Land Use $\begin{array}{llll}\text { Policy } & 27 & \text { (3): } & 801-14 .\end{array}$ https://doi.org/10.1016/j.landusepol.2009.10. 014.

Patriajaya, Anneke Clauvinia, and Yohanes Karyadi Kusliansjah. 2019. 'Hilangnya
Karakter Pedestrian Shopping Street Jalan Tunjungan Akibat Transformasi Surabaya Sebagai Kota Metropolitan'. ARTEKS : Jurnal Teknik Arsitektur 4 (1): 73-84. https://doi.org/10.30822/arteks.v4i1.81.

Prijotomo, Josef, and Galih Widjil Pangarsa. 2010. 'Rong, Wacana Ruang Arsitektur Jawa'. Issuu. Indoneisa. 2010. https://is suu.com/galihwpangarsa/docs/rong_ __wacana_ruang_arsitektur_jawa.

Purbadi, Yohanes Djarot, and Reginaldo Christophori Lake. 2019. 'Konsep KampungWis ata Sejahtera, Kreatif, Cerdas Dan Lestari Berkelanjutan'. EMARA: Indonesian Journal of Architecture 5 (1): 12-23. https://doi.org/10.29080/eija.v5i1.641.

Roberson, G., and R. Wilkie. 2010. 'Sense Of Place'. In Encyclopedia Of Geography, edited by B. Warf. United States: SAGE Publishing.

Silas, Johan. 1992. 'Government-Community Partnerships in Kampung Improvement Programmes in Surabaya'. Environment and Urbanization 4 (2): 33-41. https://doi.org/10.1177/09562478920040020 4.

Smith, Kylie M. 2011. 'The Relationship between Residential Satisfaction, Sense of Community, Sense of Belonging and Sense of Place in a Western Australian Urban Planned Community'. Edith Cowan University. https://ro.ecu.edu.au/cgi/viewcontent.cgi?arti cle $=1460 \&$ context $=$ theses . 